\title{
Sociobiology
}

RESEARCH ARTICLE - BEES

\section{The influence of habitat and species attributes on the density and nest spacing of a stingless bee (Meliponini) in the Atlantic Rainforest}

\author{
MD SILVA ${ }^{1,2}$, M RAMALHO $^{1}$ \\ 1- Universidade Federal da Bahia, Salvador-BA, Brazil \\ 2- Instituto Federal de Educação, Ciência e Tecnologia Baiano, Governador Mangabeira-BA, Brazil
}

\section{Article History}

\section{Edited by}

Evandro Nascimento Silva, UEFS, Brazil

Received 02 April 2016

Initial acceptance 11 June 2016

Final acceptance 01 August 2016

Publication date 25 October 2016

\section{Keywords}

Interference competition, patrolling mechanism, exposed nest constraint, territoriality, rubber groves.

\section{Corresponding author}

Marília Silva

Instituto Federal de Educação,

Ciência e Tecnologia Baiano

Campus Governador Mangabeira

Rua Waldemar Mascarenhas, s/n

Portão - CEP 44350000

Governador Mangabeira-BA, Brasil

E-Mail: marilia.silva@gm.ifbaiano.edu.br

\begin{abstract}
Trigona spinipes (Fabricius, 1793) lives in perennial eusocial colonies and builds nests exposed on tree branches. The reason why this generalist habitat with exposed nests cannot nest successfully in forest habitats is intriguing. This study explores the hypothesis that this species reaches higher densities in vegetation with open canopies and the subsidiary shading hypothesis, assuming the failure of large exposed nests in closed canopy rainforest. Comparative field data on nest density in open canopy vegetation (this study) and adjacent closed canopy forest (previous data) are used to test this hypothesis. At random 18 nests distributed in $4020 \times 200 \mathrm{~m}$ plots in rubber groves with a density of 1.1 nests/ha, were recorded. This is a high nest density for a single species of stingless bee and correspond to 36 times the very low density in adjacent rainforest. The high density in the rubber groves is also associated with a regular spatial distribution of nests and it suggests territorial patrolling mechanism operating at short distances (60 to $70 \mathrm{~m})$. We conclude that: (a) this species faces powerful nesting constraints in the ever green and closed canopy of rainforest, because the external structure of the nest remain wet for prolonged periods due to exposion to heavy rains and high shading; (b) the high availability of sunny sites for nesting within the deciduous and open canopy of rubber trees favours rapid nest drying and the high nest density of $T$. spinipes and realeasing its wide spread distribution where this agroforestry system dominates.
\end{abstract}

\section{Introduction}

The stingless bees occupy multiple habitat types but are particularly diverse and abundant in tropical rainforests. They depend mainly on nest structure and building materials for thermoregulation, which likely constrains their distribution to the hot tropical-subtropical zone (Sakagami, 1982; Roubik, 1989). They live in sessile, perennial and eusocial colonies, most species depend on pre-existing cavities as nesting sites, and very few species build exposed nests (Hubbell \& Johnson, 1977; Nogueira-Neto, 1997; Camargo, 2007). Because of nesting habit, some authors suggest that the density and spatial distribution of colonies should be influenced by the availability of nesting cavities, however this hypothesis has been refuted by several studies in tropical forests (Hubbell \& Johnson, 1977; Eltz et al., 2002; Silva et al., 2014). On the other hand, species building exposed nests should be less influenced by the availability of nesting sites, however this simple assumption has not been tested yet.

Intra and inter-specific interactions, flowering pattern, and colony attibutes, such as population sizes, are also assumed to play a role in regulating density and spacing of nests in local populations and communities of stingless bees (Hubbell \& Johnson, 1977; Johnson, 1987; Eltz et al., 2003; Biesmeijer \& Slaa, 2006).

Here, Trigona spinipes (Fabricius, 1793) is used as a model to investigate factors affecting nest density and nesting spatial pattern of stingless bees, because it builds huge 
exposed nests with very populous colonies (rough estimates from 5,000-180,000 individuals; e.g. Almeida \& Laroca, 1988; Camargo, 2007; see also Biesmeijer \& Slaa, 2006), with high demands for food sources throughout the year. Moreover, their workers are extremely aggressive against potential intruders in the vicinity of the colony (Shakleton et al., 2014) and they are refered to be territorial, without a clear evidence on the role of such aggressiveness on nest spacing.

T. spinipes is widely distributed in the tropics and subtropics of South America (Almeida \& Laroca, 1988; Silveira et al., 2002; Camargo, 2007) and it visits the flowers of many plant species in open vegetation habitats (CortopassiLaurino \& Ramalho, 1988; Almeida \& Laroca, 1988; Knoll, 1990; Martins, 1994; Silveira \& Campos, 1995; Aguiar \& Martins, 1997; Carvalho \& Marchini, 1999; Viana, 1999), but barely in the flowerings of closed canopy forest (Ramalho, 2004). In some nest census of $T$. spinipes (Taura \& Laroca, 1991; Henriques, 1997; Batista et al., 2003; Pioker-Hara, 2011; Silva et al., 2013), the lowest density was observed in the closed canopy forest (Silva et al., 2013), and the highest density in open canopy habitats. (Roubik, 1989; Henriques, 1997).

The hypothesis put forth in this study is that $T$. spinipes faces powerful nesting constraints in the ever green and closed canopy of tropical rainforest, throughout its wide ecological distribution. It builds exposed nests on tree branches, that probably provides adequate heat up take to thermoregulation (Zucchi \& Sakagami, 1972; Almeida \& Laroca, 1988) under subtropical conditions. Due to its apparent reliance on exposure of the nest to direct sunlight, we assume that the main constraint on its nesting success relates to the degree of canopy shading. In the tropical forest, nest humidity is probably a constraint to huge exposed nests, because the more closed the canopy, the more slowly the nests will dry, especially in high rainfall evergreen forest. This hypothesis is tested by using comparative data on density and spacing of nests in open canopy habitat (rubber groves) and adjacent rainforest closed canopy habitat (rainforest). The understanding of the role of wood grooves with open canopy (such as rubber and eucalyptus) on the ecological expansion of T.spinipes might be important to management of this species in rural areas spreading on previous forested areas; first, because it is part of a group of stingless bees with extensive record of floral theft and damage to flowers both in natural habitats and orchards (Renner, 1983; Roubik, 1989); second, due to the increasing deforestation of tropical forests (e.g. Brazilian Atlantic Forest) .

\section{Material and Methods}

The study landscape is located in the northern portion of the Central Corridor of the Brazilian Atlantic Forest within the limits of 'Reserva Ecológica Michelin' (REM) (1350' S and $\left.39^{\circ} 15^{\prime} \mathrm{W}\right)$. The REM protects three remnants of Closed Canopy Dense Tropical Evergreen Rainforest (140, 550, 625 ha) at altitudes ranging from 40-330m (Flesher, 2006), under
Af climate type (Köppen classification 1948), with average monthly temperatures ranging from 18 to $30^{\circ} \mathrm{C}$, relative humidity between $80 \%$ and $85 \%$, and annual rainfalls of around $2,000 \mathrm{~mm}$.

Rubber (Hevea brasiliensis Muell. Arg), and rubber/ cacao plantations lie to the south and east of the forest remnants covering $>5000$ ha with many small forest fragments $(<10 \mathrm{ha})$ of pioneer forest on rocky outcrops and along the water ways. In the plantation the rubber trees are spaced in $3 \mathrm{~m}$ lines and $7 \mathrm{~m}$ between lines, resulting in a density of around 500 adult trees per hectare (Flesher, 2006), with a basal diameter greater than $14 \mathrm{~cm}$ (circumference at breast height above $160 \mathrm{~cm}$ ) and an upper canopy $8-18 \mathrm{~m}$ high. It is common for the inter-row vegetation to be cut back once every 6-12 months. Rubber is a deciduous tree, changing all of its leaves once a year, mostly during the cooler wetter months (July and August) which creates a profound physiognomy and microclimate change, with the entire canopy exposed to full sunlight and increased sunlight reaching the understory.

\section{Nest sampling}

The nests were sampled in two habitats that represents the two extremes of canopy exposure to sunlight: the more open deciduous rubber grove canopies that are exposed to direct sunlight for 1-2 months each year; and the dense closed evergreen canopies of the rainforest. We used data on nest density of stingless bees in the rainforest of the REM (Silva et al., 2013) to compare with a density measure collected in the rubber plantation.

T. spinipes builds exposed nests on medium and large tree branches and in vacant arboreal termite mounds (Roubik, 1989; Zucchi et al., 1993; Vieira et al., 2007; Camargo, 2007) which makes is easy to detect these large and conspicuous nests (Fig.1) by visual searching. The nests were sampled in 4020 x 200m plots (totalling 16ha), which were randomly distributed in 2,000 ha of rubber groves. The plots were sampled monthly for five consecutive days between August and December 2010. The nests were georeferenced (GPS Garmin 60CS) and some bee specimens were collected checking in order to ensure that the species inhabiting the nests were T. spinipes. Bee specimens were identified by Dr. Favizia Freitas de Oliveira of the Insect Bionomics, Biogeography, and Systematics Laboratory (BIOSIS) at Federal University of Bahia - UFBA, and they were deposited in the Zoology Museum at UFBA (MZUFBA) and in the Pollination Ecology Laboratory (ECOPOL-UFBA).

\section{Data analysis}

The permutation t-test (10.000 permutations) were used to test for the equality of densities in both habitats (Anderson, 2001), considering random samples with excess zero-count data (very small probability of occurrence per 


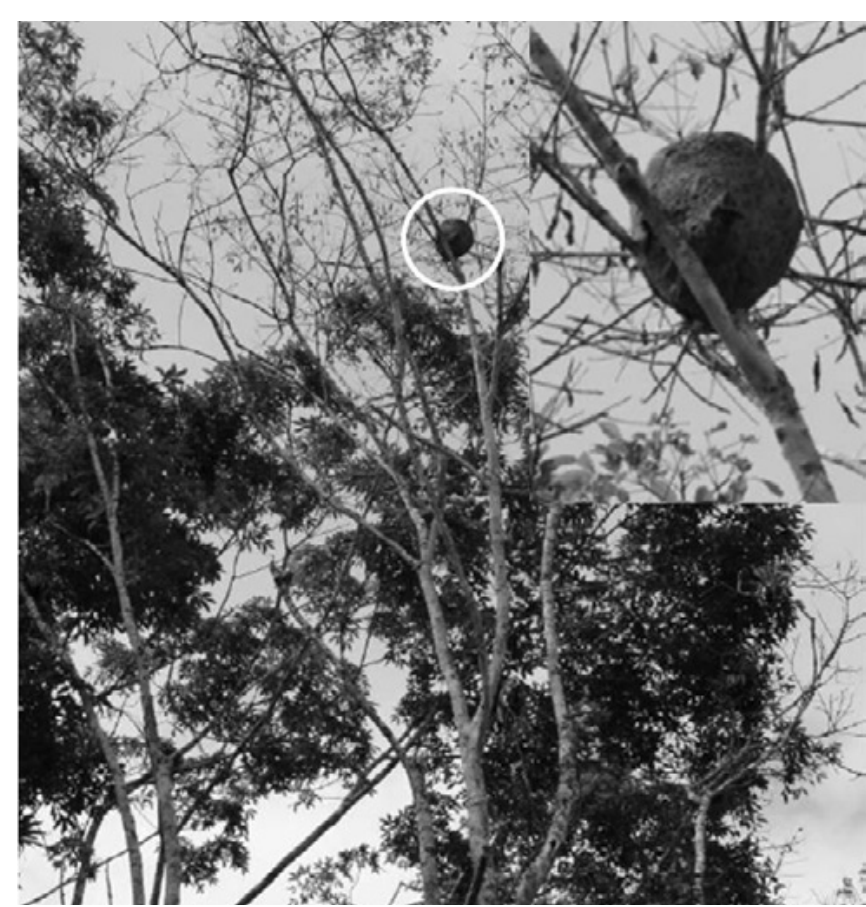

Fig 1. Trigona spinipes (Fabricius, 1793) exposed nest in a rubber tree at Michelin Ecological Reserve (MER).General view and close (righ corner). plot unit) and likely the Poisson-distribution of data. The spatial distribution of the nests was evaluated with the nearest neighbour (R) dispersion index (Clark \& Evans, 1954), using the software Ecological Methodology, 2nd edition (Kenney $\&$ Krebs, 2000). The dispersion index is the ratio between the observed average distance from nearest neighbour and the expected average distance from the nearest neighbour if the nests were randomly distributed (aggregated distribution $\mathrm{R}$ $<0$, random $\mathrm{R}=1$, and uniform $\mathrm{R}>1$ ).

\section{Results and Discussion}

18 nests of $T$. spinipes were recorded in the 16 hectare of rubber groves sampled, with a density of 1.1 nests/ha (Table 1). This high density for a species of stingless bee contrasts to rarity of its nests in adjacent forest habitats (Silva et al., 2013) where a very low frequency of individuals (3.2\%) was also observed foraging on attractive baits (Silva et al., 2008). Independent sampling of nests (Table 1) and bees visiting flowers in many habitat types showed that $T$. spinipes is common in open vegetation habitats and uncommon in forest (Knoll, 1990; Martins, 1994; Silveira \& Campos, 1995; Aguiar \& Martins, 1997; Carvalho \& Marchini, 1999; Viana,

Table 1. Density of nests of eusocial bee Trigona spinipes in different habitats in Brazil. Undetermined spatial distribution is related to very low nest densities and then to large and unaccessed distances between neighbor nests.

\begin{tabular}{|c|c|c|c|c|}
\hline Habitat Type & Density (Nest/ha) & Spatial Distribution & Nesting Height & References \\
\hline Anthropic (Urban) & 0,096 & Undetermined & $10 \mathrm{~m}$ & Freitas, 2001 \\
\hline Anthropic (Urban) & 0,12 & Undetermined & $11,1 \mathrm{~m}$ & Souza et al., 2005 \\
\hline Anthropic (Urban) & 0,18 & Undetermined & $10 \mathrm{~m}$ & Taura \& Laroca 1991 \\
\hline Anthropic (Urban) & 0,023 & Undetermined & - & Sousa et al., 2002 \\
\hline Anthropic (Urban) & 0,033 & Undetermined & $14 \mathrm{~m}$ & Silva \& Ramalho, in press \\
\hline $\begin{array}{c}\text { Savannah/Steppe } \\
\text { (semi-arid Caatinga) }\end{array}$ & 0,4 & Undetermined & $6 \mathrm{~m}$ & Teixeira \& Viana, 2005 \\
\hline $\begin{array}{l}\text { Tropical Savannah } \\
\text { (Brazilian Cerrados) }\end{array}$ & 0,3 & Undetermined & - & Henriques, 1997 \\
\hline $\begin{array}{l}\text { Tropical Savannah } \\
\text { (Brazilian Cerrados) }\end{array}$ & 0,56 & Random and clumped & 2,2 & Pioker-Hara, 2011 \\
\hline $\begin{array}{c}\text { Tropical Rain Forest } \\
\text { (Brazilian Atlantic Forest) }\end{array}$ & 0,265 & Undetermined & $16,8 \mathrm{~m}$ & Batista et al., 2003 \\
\hline $\begin{array}{c}\text { Tropical Forest } \\
\text { (Brazilian Atlantic Forest) }\end{array}$ & 0,025 & Undetermined & - & Mateus et al., 2009 \\
\hline $\begin{array}{c}\text { Tropical Forest } \\
\text { (Brazilian Atlantic Forest) }\end{array}$ & 0,039 & Undetermined & - & Siqueira \& Ferreira, 2007 \\
\hline $\begin{array}{c}\text { Tropical Forest } \\
\text { (Brazilian Atlantic Forest) }\end{array}$ & 0,014 & Undetermined & - & Werneck et al., 2007 \\
\hline $\begin{array}{c}\text { Tropical Rain Forest } \\
\text { (Brazilian Atlantic Forest) }\end{array}$ & 0,031 & Undetermined & $12 \mathrm{~m}$ & Silva et al., 2013 \\
\hline Rubber Tree Plantation & 1,1 & Uniform & $10 \mathrm{~m}$ & This study \\
\hline
\end{tabular}


1999; Ramalho, 2004). An apparent exception would be the moderate nest density observed by Batista et al., (2003) in a very small and narrow patch (100-200m wide) of disturbed forest bordering a water resorvoir in a suburban landscape, where the nest density were likely influenced by a strong edge effect.

On the rubber trees, the large exposed nests of $T$. spinipes were built around branches between 6 and $16 \mathrm{~m}$ height $(10.2 \mathrm{~m} \pm 3.2 \mathrm{~m})$. In general, this species builds nests on the upper canopy of trees, and nests at low heights are only recorded in absence of large trees (Table 1). Assuming its tight association with tree canopy (e.g. Wille \& Michener, 1973; Roubik, 2006), the high availability of nesting sites in both the rubber groves and the forest does not explain the significant variation in the observed density between these two habitats $(\mathrm{p}=0.0001$, permutation $\mathrm{t}$ test; see also Silva et al., 2013).

The much higher density of $T$. spinipes in the rubber groves than in the adjacent forest could not be explained by availability of flower sources either, because there are fewer flower resources throughout the year in the rubber groves than in the forest. Since other stingless bee species with high food demands reached high nest densities (3.5 nests/ha) in the REM forest (Silva et al., 2013), the availability of floral resources or flowering pattern (e.g. Eltz et al., 2002) per se does not provide a satisfactory explanation for the low nest density of T. spinipes in this habitat, either. Moreover, tropical lowland forests often support a high diversity and abundance of stingless bees, which depend on the continuous and abundant floral resources to maintain their populous perennial colonies (eg. Roubik, 1993; Ramalho, 2004).

On the other hand, Cortopassi-Laurino \& ImperatrizFonseca (2009) observed that the nests of $T$. spinipes were often associated with deciduous trees that loose their leaves during the drier and colder season (e.g. Chorisia speciosa St.-Hil.), thus increasing exposure to direct sunlight and heat absorption assumed to be necessary for thermoregulation (Zucchi \& Sakagami, 1972; Almeida \& Laroca, 1988).

In the REM, the rubber trees loose their leaves seasonally and mainly during June and August, when the rainfall is more frequent and the temperature drops by up to $19^{\circ} \mathrm{C}$. These favorable physical conditions whith in this open canopy are likely responsible for the high density of nests in the rubber groves. In contrast, the closed shaded canopy in the adjacent rainforest provides poor nesting habitat. However, it is unlikely that restrictions on direct absorption of heat from sunlight play a role in thermoregulation of such populous colonies, under moderate air temperatures (around $20^{\circ} \mathrm{C}$ ), in the whole range of tropical lowland forests. Exposed to heavy rains, the external structure of its huge nest remain wet for prolonged and we suggest $T$. spinipes depends on direct insolation to keep its nests dry and fungus-free. In the tropical forest, nest humidity is probably a constraint to huge exposed nests, because the more closed the canopy, the more slowly the nests will dry, especially in high rainfall evergreen forest. In contrast, the high availability of sunny sites for nesting within the deciduous and open canopy of rubber trees favours rapid drying of external nest structures and realeasing the high nest density and wide spread distribution of $T$. spinipes where this agroforestry system dominates.

The results of this study in the REM show that the large difference in nest density of $T$. spinipes between adjacent habitats with very distinctive canopy shading supports the argument that shading is a powerful constraint in the selection of appropriate nesting sites. Whether for thermoregulation or reducing nest moisture after heavy rains, the dependence on direct insolation is likely the the principal habitat variable that constrains the use by $T$. spinipes of the closed canopy tropical rainforests. The rubber groves, with upper tree canopies exposed to the full sun, favor the occupation of this extensive agroforestry landscape by this stingless bee. As nest density rises and approaches the density threshold, the species'patrolling mechanism becomes effective and regulates nest densities resulting in the uniform distribution of $T$. spinipes colonies in the rubber groves.

This study in the rubber plantations had the highest $T$. spinipes density observed to date (Table 1). Most previous studies has detected low nest density, and undetermined spatial pattern due to nonaccessed distances between nearest neighbor nests $(>90 \mathrm{~m}<400 \mathrm{~m}$ based on nest densities in Table 1). At intermediate density (0.56 nests/ha), Pioker-Hara (2011) recorded random or clumped nest spacing in the tropical savannah.

At low or moderate densities (Table 1), the spacing of T.spinipes nests (e.g. $>90 \mathrm{~m}$ ) should be poorly influenced by inter-colonial interactions because the degree of agonistic behavior (Shakleton et al., 2014 ) likely depends on the distances between nests and home range of colonies (Hubbell \& Johnson, 1977). In contrast, in the rubber groves the spatial distribution of nests is even $(\mathrm{R}=2.02)$ (Fig 2) probably because the density of T.spinipes is high enough to make the patrolling by workers an effective territorial mechanism of spacing in this habitat.

Assuming the home range of colonies of stingless bees could be estimated by the inverse density of nests (Hubbell \& Johnson, 1977), nest densities of 1.0 and 0.6 nest/ha indicates a patrolling distance threshold between $60 \mathrm{~m}$ and $70 \mathrm{~m}$ to produce even nest spacing in $T$. spinipes. Therefore, even for such a huge nest population, patrolling could prevent the establishment of new nests only at short distances. Besides scalate aggressiviness towards co-specifics (Hubbel \& Johnson, 1977), and very large woker population, such patrolling mechanism is likely supported by the ability of $T$. spinipes to use directional olfactory stimuli to fast attraction of nest-mates to very specific sites (Nieh et al., 2004) and at the very beginning of swarming process of competing colonies. In synthesis, use of aggression to control nest density is likely a very exceptional territorial mechanisms in stingless bee that could be effectively used at short distances. 


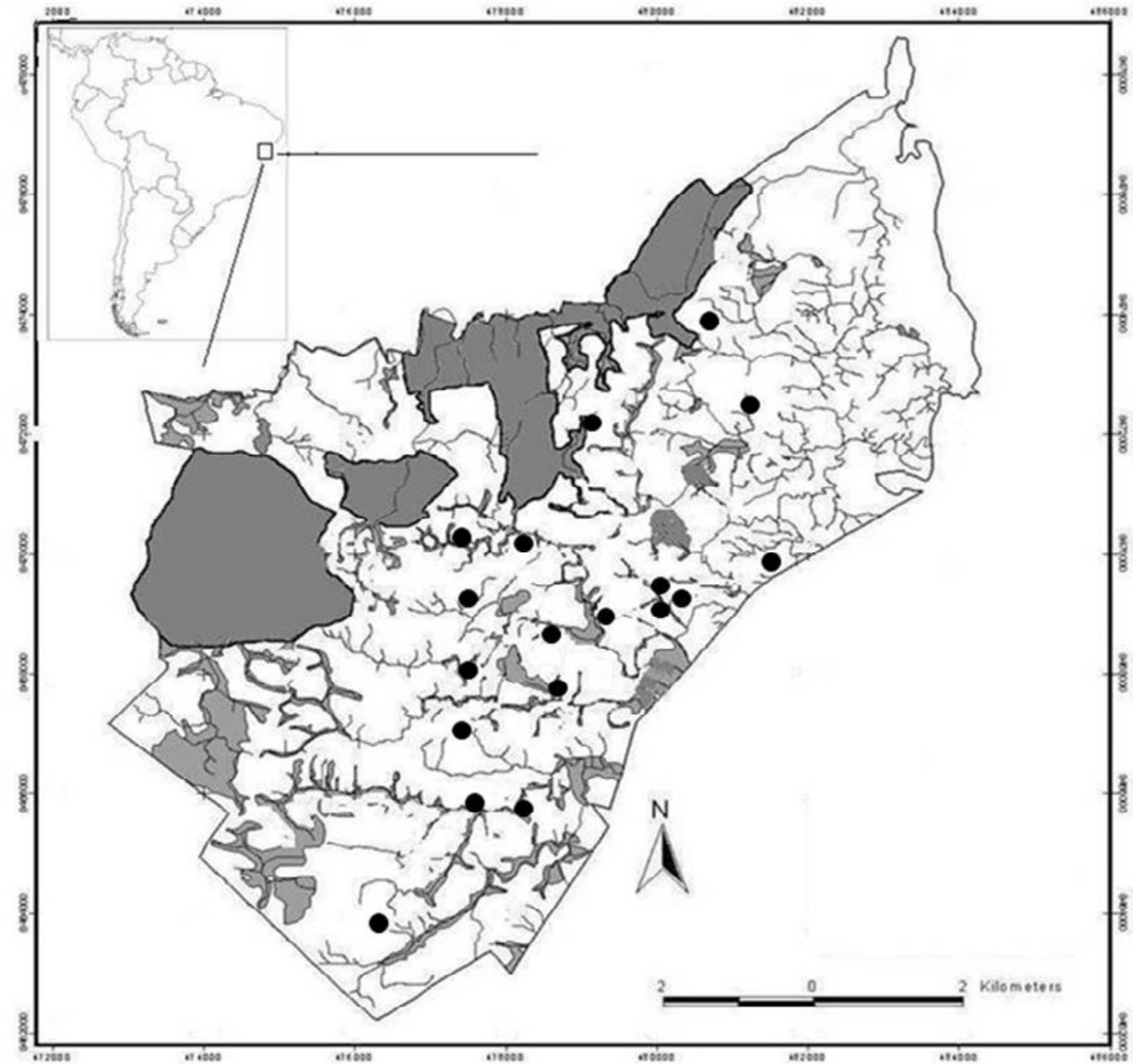

Fig 2. Spatial distribution of T. spinipes nests (black circles) in the 'Reserva Ecológica Michelin' (REM). The dark grey areas are rainforest remnants (Brazilian Atlantic Forest). The white areas are mainly covered by rubber tree groves intercropped with cacao and banana, and crossed by gallery forest of pioneer vegetation.

\section{Acknowledgments}

To Michelin for logistic support. To Dr. Kevin Flesher for reviewing the English and useful suggestions. To CAPES, for the doctoral scholarship to the first author. To CNPq (Process $\mathrm{n}^{\mathrm{o}} 481113 / 2004-5$ e 478271/2008) and FAPESB (APR0114/2006) for the research financial support. To UFBA (edital PROPI-2014) for the productivity scholarship to the second author.

\section{References}

Aguiar, C.M.L., Martins, C.F. (1997). Abundância relativa, Diversidade e Fenologia de Abelhas (Hymenoptera, Apoidea) na Caatinga, São João do Cariri, Paraíba, Brasil. Iheringia, Série. Zoologia, Porto Alegre, 83:151-163.

Almeida, M.C., Laroca, S. (1988). Trigona spinipes (Apidae, Meliponinie): Taxonomia, bionomia e relações tróficas em áreas restritas. Acta Biológica Paranaense, 1: 67-108.
Anderson, M.J. (2005). Permanova: Permutational multivariate analysis of variance - A computer program. Departament of Statistics, University of Auckland, New Zealand.

Biesmeijer, J.C., Slaa, E.J. (2006). The structure of eusocial bee assemblages in Brazil. Apidologie, 37: 240-258. doi: 10.1051/apido:2006014

Batista, M.A., Ramalho, M., Soares, A.E.E. (2003). Nesting sites and abundance of Meliponini (hymenoptera: Apidae) in heterogeneous habitats of the atlantic rain forest, Bahia, Brazil. Lundiana, 4: 19-23. doi:10.1590/S1519-566X2007000100005

Camargo, J. M. F. (2007). Trigona spinipes. In J. S. Moure, D. Urban \& G.A.R. Melo (orgs.), Catalogue of Bees (Hymenoptera, Apoidea) in the Neotropical Region. Curitiba, Sociedade Brasileira de Entomologia, 1058p.

Carvalho, C.A.L., Marchini, L.C. (1999). Abundância de ninhos de Meliponinie (Hymenoptera: Apidae) em biótopo urbano no município de Piracicaba-SP. Revista de Agricultura, $1: 35-44$. 
Clark, P.J., Evans, F.C. (1954). Distance to nearest neighbour as a measure of spatial relationships in populations. Ecology, 35: 445-453.

Cortopassi-Laurino, M, Ramalho, M. (1988). Pollen harvest by Africanized Apis mellifera and Trigona spinipes in São Paulo. Botanical and Ecological views. Apidologie, 19: 1-24.

Cortopassi-Laurino, M., Alves, D.A.E., Imperatriz-Fonseca, V.L. (2009). Árvores Neotropicais, Recursos Importantes Para A Nidificação De Abelhas Sem Ferrão (Apidae, Meliponini). Mensagem Doce, 100: 21-28.

Eltz, T., Brühl, C.A., Kaars, S.V., Linsenmair, K.E. (2002). Determinants of stingless bee nest density in lowland dipterocarp forests of Sabah, Malaysia. Oecologia, 131: 27-34. doi: 10.1007/s00442-001-0848-6

Flesher, K.M. (2006). The biogeography of the medium and large mammals in a umandominated landscape in the Atlantic Forest of Bahia, Brazil: evidence for the role of agroforestry systems as wildlife habitat. (Doctoral Thesis). Program in Ecology and Evolution. School-New Brunswick Rutgers, The State University of New Jersey, 624p.

Freitas, G. S. (2001). Levantamento de ninhos de meliponíneos (Hymenoptera, Apidae) em área urbana: Campus da USP, Ribeirão Preto/SP. Ribeirão Preto, 84 f: Dissertação (Mestrado Entomologia) - Faculdade de Filosofia, Ciências e Letras de Ribeirão Preto, Universidade de São Paulo.

Henriques, R.P.B. (1997). Nest density of Trigona spinipes (Hymenoptera: Apidae) in cerrado vegetation of central Brazil. Revista de Biologia Tropical, 45: 700-701.

Hubbell, S.P., Johnson, L.K. (1977). Competition and Nest Spacing in a Tropical Stingless Bee Community. Ecology, 58: 950-963. doi: 10.2307/1936917

Johnson, L. K. (1987). Defense of food supply by eusocial colonies. American Zoologist, 27: 347-358.

Kenney, A.J., Krebs, C.J. (2000). Programs for Ecological Methodology, 2nd ed. Vancouver, Dept. of Zoology, University of British Columbia.

Knoll, F.R.N. (1990). Abundância realtiva, sazonalidade e preferências florais de Apidae (Hymenoptera) em uma área urbana. Tese (Doutorado) IB-USP.127p.

Köppen, W. (1948). Climatologia: con un estudio de los climas de la terra. México. Fondo de Cultura Economica, 479p.

Martins, C.F. (1994). Comunidade de abelhas (Hymenoptera, Apoidea) da caatinga e do cerrado com elementos de campo rupestre do Estado da Paraíba. Revista Nordestina de Biologia, 9: 225-257.

Mateus, S., Rodrigues Pereira, U.C., Cabette, H.S.R., Zucchi, R. (1999). Locais de Nidificação das Abelhas Nativas sem Ferrão (Hymenoptera, Apidae, Meliponinae) do Parque Municipal do Bacaba, Nova Xavantina - MT. Mensagem Doce, 100: 60-62.
Nieh, J.C., Contrera, F.A.L., Yoon, R.R., Barreto, L.S., Imperatriz-Fonseca, V.L. (2004). Polarized short odor-trail recruitment communication by a stingless bee, Trigona spinipes. Behavioral Ecology and Sociobiology, 54: 435-448. doi: 10.1007/s00265-004-0804-7

Nogueira Neto, P. (1997). Vida e criação de abelhas indígenas sem ferrão. São Paulo: Nogueirapis, 445p.

Pioker-Hara, F.C. (2011). Determinantes da densidade e distribuição de ninhos e diversidade de espécies de meliponíneos (Apidae, Meliponini) em áreas de cerrado de Itirapina, SP. Tese (Doutorado) - Instituto de Biociencias-USP, 238p.

Ramalho, M. (2004). Stingless bees and mass flowering trees in the canopy of Atlantic Forest: a tight relationship. Acta Botanica Brasilica, 18: 37-47. doi:10.1590/S0102-330 62004000100005

Renner, S. (1983). The widespread occurrence of anther destruction by Trigona bees in Mealastomataceae. Biotropica, 15: 251-256. doi: 10.2307/2387649

Roubik, D. W. (1989). Ecology and natural history of tropical bees. Cambridge University Press, 514p.

Roubik, D.W. (1993). Direct costs of forest reproduction, bee-cycling and the efficiency of pollination modes. Journal of Biosciences, 18: 537-552. doi: 10.1007/BF02703085

Roubik, D.W. (2006). Stingless bee nesting biology. Apidologie, 37: 124-143. doi: 10.1051/apido:2006026

Sakagami, S.F. (1982). Stingless bees. Pp.361-423 In: Herman H R (ed.). Social insects. Academic Press, New York.

Shackleton, K. A. 1., Toufailia, H., Balfou, N.J., Nascimento, F.S., Alves, D.A., Ratnieks, F.L.W. (2014). Appetite for self-destruction: suicidal biting as a nest defense strategy in Trigona stingless bees. Behavioral Ecology and Sociobiology, 69: 273-281. doi: 10.1007/s00265-014-1840-6.

Silva, M., Ramalho, M., Florence, C.T., Leão, P.C.G., Oliveira, J.P.L., Monteiro, M., Rosa J.F., Almeida, M.A. (2008). Heterogeneidade Espacial e Diversidade De Abelhas Meliponini na Mata Atlântica (RPPN da Michelin, Bahia). Sitientibus Série Ciências Biologicas, 8: 298-301.

Silva, M.D., Ramalho, M., Monteiro, D. (2013). Diversity and habitat use by stingless bees (Apidae) in the Brazilian Atlantic Forest. Apidologie, 44: 699-707. doi: 10.1007/s13592-013-0218-5

Silva, M.D., Ramalho, M. \& Monteiro, D. (2014). Communities of social bees (Apidae: Meliponini) in trap-nests: the spatial dynamics of reproduction in an area of Atlantic Forest. Neotropical Entomology, 43: 307-313. doi: 10.1007/s13744014-0219-8

Silveira, F.A., Campos, M.J.O. (1995). A melissofauna de Corumbataí (SP) e Paraopeba (MG) e uma análise da biogeografia das abelhas do cerrado brasileiro (Hymenoptera, Apoidea). Revista Brasileira de Entomologia, 39: 371-401. 
Silveira, F.A., Melo, G.A.R. \& Almeida, E.A.B. (2002). Abelhas brasileiras: sistemática e identificação. Fundação Araucária, 253p.

Siqueira, E.L., Ferreira-Nogueira, F.H. (2007). Hábitos de Nidificação das abelhas sem ferrão (Hymenoptera, Meliponini), em uma região às margens do Rio Araguari-MG. Anais do VII Congresso de Ecologia do Brasil, Caxambu.

Sousa, L.A., Pereira, T. O., Prezoto. F., Faria-Mucci, G.M. (2002). Nest foundation and diversity of Meliponini (Hymenoptera, Apidae) in an urban area of the municipality of Juiz de Fora, MG, Brazil. Bioscience Journal, 18: 59-65.

Souza, S.G.X., Teixeira, A.F.R., Neves, E.L., Melo, A.M.C. (2005). As abelhas sem ferrão (Apidae; Meliponini) residentes no campus Federação/Ondina da Universidade Federal da Bahia, Salvador, Bahia, Brasil. Candombá - Revista Virtual, 1: 57-69.

Taura, H.M., Laroca, S. (1991). Abelhas altamente sociais (Apidae) de uma área restrita em Curitiba (Brasil): Distribuição dos ninhos e abundância relativa. Acta Biologica Paranaense, 20: 85-101.

Teixeira, A.F.R., Viana, B.F. (2005). Distribuição e densidade dos sítios nidificados pelos meliponíneos (Hymenoptera; Apidae) das dunas do médio São Francisco. Revista Nordestina de Zoologia, 2: 05-20. doi: 10.1590/S008556262002000400012

Viana, B.F. (1999). Biodiversidade da apifauna e flora apícola das dunas litorâneas da APA das lagoas e Dunas de Abaeté, Salvador-Bahia-Composição, fenologia e suas interações.Tese (doutorado). IB-USP, 168p.
Vieira, C.U., Rodovalho, C.M., Almeida, L.O., Siquieroli, A.C.S., Bonetti, A.M. (2007). Interação entre Trigona spinipes Fabricius, 1793 (Hymenoptera: Apidae) e Aethalion reticulatum Linnaeus, 1767 (Hemiptera: Aethalionidae) em Mangifera indica (Anacardiaceae). Bioscience Journal, Supplement 1, 23 : 10-13. doi: 10.12741/ebrasilis.v2i2.41

Wille, A., Michener, C.D. (1973). The nest architecture of stingless bees with special reference to those of Costa Rica (Hymenoptera: Apidae). Revista de Biologia Tropical, 21: 3-278.

Werneck, A.H., Faria-Mucci, G.M., Campos, L.A.O. (2007). Ninhos de abelhas sem ferrão (Hymenoptera: Apidae, Meliponini) encontrdos na Estação Ecológica de Água Limpa-Cataguases/MG. Anais do VII Congresso de Ecologia do Brasil. Caxambu.

Zucchi, R.A., Silveira Neto, S., Nakano, O. (1993). Guia de Identificação de Pragas Agrícolas. Piracicaba, FEALQ, 139p.

Zucchi, R. \& Sakagami, S.F. (1972) Capacidade termoreguladora em Trigona spinipes e em algumas outras espécies de abelhas sem ferrão (Hymenoptera: Apidae: Meliponinae). Livro em Homenagem a Warwik Estevan Kerr. (eds C. CruzLandim, N.J. Hebling, E. Lello \& C.S. Takahashi), pp. 301309. UNESP, Rio Claro.

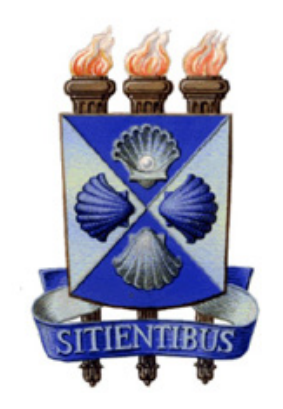

